\title{
Dynamic Modeling of Planar Solid Oxide Fuel Cell System for Regional Jet Aircraft Application (Simple System)
}

\author{
Golnaz Pourabedin ${ }^{1}$, Fatholah Ommi ${ }^{1 *}$ \\ ${ }^{1}$ Department of Mechanical Engineering, Aerospace Faculty, Tarbiat Modares University, Tehran, Iran \\ *Corresponding Author: Fathollah ommi, Department of Mechanical engineering, Tarbait Modares \\ University, Tehran, Iran
}

\begin{abstract}
The analysis offuel cells can be dividedinto two modes, steady-state modeling, and dynamic modeling. Our previous paper [1] focused on steady state operation of solid oxide fuel cell for aircraft APU. The purpose of this paper is to evaluate the transient behavior of the jet fuel external reforming solid oxide fuel cell system plus one heat exchanger (for air preheating) to sudden current load changes. The present model solves the mass, energy, and electrochemical equations for a solid oxide fuel cell, and calculates the thermal response time of the heat exchanger. In this paper, the SOFC heat-up stage and the output voltage and efficiency response to a sudden load change at regional jet flight cycle are investigated.

The results show that heat exchanger temperature variations will reach steady state after about 50 seconds. The heat transfers to anode interconnector layer are almost double and the more current load changes, the more impact the system performance will be. Also by sudden load current changes, the activation and ohmic voltage variations are the highest in the main engine start stage and conversely, concentration voltage and double layer charging variations are the lowest.
\end{abstract}

Keywords: Solid Oxide Fuel cell, APU, Aircraft, heat up, Simulink, Dynamic Modeling, Current load, Step change.

\section{INTRODUCTION}

Conventional electric power generation based on hydrocarbon fuels causes high pollution and generates power with relatively low efficiency. In aviation and in other remote power applications, like in the auto industry, weight and volume also become important design considerations. The emerging fuel cell technology offers a promising solution for powering future aircraft with reduced emissions, higher efficiencies, and with lower weights and volumes. Especially, the emissions from the fuel cells are known to be the lowest for an all of the fossil fuels [2]. The SOFC auxiliary power unit (APU) draws the interest of many researchers because of its high efficiency, low emission and high generation capability [3].

The SOFC technology faces many challenges when it comes to commercialization, since cost reductions, increasing the reliability of components and extended durability are required [3]. To overcome these challenges, one needs to understand the complex operating mechanism of the SOFC stack, such as heat and mass transfer, together with electrochemical reactions. Therefore, it is increasingly important to understand the fundamental mechanisms and SOFC behaviors under transient operating conditions.

There are many examples of modeling investigations for aircraft APU in literature. Most models, however, are in steady state condition and tubular solid oxide fuel cells [4-9].

In this paper, we modeled dynamic behavior of a jet external reforming solid oxide fuel cell system plus one heat exchanger for air preheating to sudden current load changes for airplane APU applications.

\section{MODEL DES CRIPTION}

As the experimental investigations on SOFCs are time-consuming and expensive, mathematical modeling techniques have been proved to be a cost-effective method to investigate both steady state and transient behavior of SOFCs. The overall aim of the present study is to evaluate the performance of a planar SOFC system for aircraft APU applications in transient conditions. Results of the cell and system models in steady state condition have been previously published in [1]. Only a brief description of the SOFC mathematical model applied is given here (for details see [1]). 
The conservation equations govern the mass transport and the temperature and flow rates of the species. Ions transport through the porous and electrolyte media to the TPB. The charge transfer kinetics governs at the TPB.

In this section, we examine the transient phenomena for the SOFC system and provide the dynamic model equations for each one. A time variable model for the heat exchanger is presented too.

\subsection{Planar SOFC model}

The principle conserved quantities needed in fuel cell performance modeling are energy and mass. A dynamic equation for the conservation of momentum is not often of interest given the relatively low pressure drops seen in fuel cell operation, and the relatively slow fluid dynamics employed [10]. These equations are expressed as one-dimensional, lumped volume models.

The continuity equations determined through the ideal gas assumption comprise the anode and cathode molar flow rate variations and effective partial pressures of the component in channels due to the reactions:

$\begin{array}{ll}\frac{\mathrm{v}_{\mathrm{a}}}{\mathrm{RT}_{\mathrm{F}}} \frac{\mathrm{d} \dot{\mathrm{P}}}{\mathrm{dt}}=\left(\mathrm{n}_{\mathrm{in}, \mathrm{i}}-\dot{\mathrm{n}}_{\text {out }, \mathrm{i}}\right)+\sum_{\mathrm{j}=\mathrm{Ox}} \mathrm{v}_{\mathrm{i}, \mathrm{j}} \mathrm{r}_{\mathrm{j}} \frac{1}{\mathrm{~A}_{\mathrm{a}}} & \mathrm{i} \in\left\{\mathrm{H}_{2}, \mathrm{H}_{2} \mathrm{O}\right\} \\ \frac{\mathrm{v}_{\mathrm{c}}}{\mathrm{RT}_{\mathrm{A}}} \frac{\mathrm{dP}}{\mathrm{dt}}=\left(\mathrm{n}_{\mathrm{in}, \mathrm{i}}-\dot{\mathrm{n}}_{\text {out }, \mathrm{i}}\right)+\mathrm{v}_{\mathrm{i}, \mathrm{Red}} \mathrm{r}_{\mathrm{Red}} \frac{1}{\mathrm{~A}_{\mathrm{c}}} & \mathrm{i} \in\left\{\mathrm{N}_{2}, \mathrm{O}_{2}\right\}\end{array}$

As described in [1], to improve the accuracy of the thermal model, five layers of temperatures are considered in energy balance equations. Radiation between solid parts is also considered in the thermal model. Therefore, for each unit element, the energy balance equations are written for the fuel and air channels, PEN, and air and fuel interconnectors through the lumped temperature assumption as:

$$
\begin{aligned}
& \dot{\mathrm{q}}_{\text {chem }}-\dot{\mathrm{q}}_{\text {elec }}-\dot{\mathrm{q}}_{\text {conv,air }}+\dot{\mathrm{q}}_{\text {conv,fuel }}+\dot{\mathrm{q}}_{\text {air,flow }}+\dot{\mathrm{q}}_{\text {fuel,flow }}+\dot{\mathrm{q}}_{\text {Rad,IA }}+\dot{\mathrm{q}}_{\text {Rad,IF }}= \\
& \mathrm{m}_{\mathrm{PEN}} \mathrm{C}_{\mathrm{PEN}} \frac{\mathrm{dT}}{\mathrm{dt}} \\
& \dot{\mathrm{q}}_{\text {conv,fuel }}+\dot{\mathrm{q}}_{\text {fuel,flow }}-\dot{\mathrm{q}}_{\text {fuel,flow }}=\mathrm{m}_{\text {fuel }} \mathrm{C}_{\text {fuel }} \frac{\mathrm{dT}_{\mathrm{F}}}{\mathrm{dt}} \\
& \dot{\mathrm{q}}_{\text {conv,air }}+\dot{\mathrm{q}}_{\text {air,flow }}-\dot{\mathrm{q}}_{\text {air,flow }}=\mathrm{m}_{\text {air }} \mathrm{C}_{\text {air }} \frac{\mathrm{dT}_{\mathrm{A}}}{\mathrm{dt}} \\
& \dot{\mathrm{q}}_{\text {Rad,IF }}-\dot{\mathrm{q}}_{\text {fuel,flow }}=\mathrm{m}_{\mathrm{IF}} \mathrm{C}_{\mathrm{IF}} \frac{\mathrm{dT}_{\mathrm{IF}}}{\mathrm{dt}} \\
& \dot{\mathrm{q}}_{\text {Rad,IA }}-\dot{\mathrm{q}}_{\text {air,flow }}=\mathrm{m}_{\mathrm{IA}} \mathrm{C}_{\mathrm{IA}} \frac{\mathrm{dT}_{\mathrm{IA}}}{\mathrm{dt}}
\end{aligned}
$$

The thermal time constant through the lumped temperature assumption in Convection existence defined as: $\tau_{t}=\frac{\left(m_{P E N} C_{P E N}\right)}{\left(h_{P E N} A_{P E N}\right)}$. But the equivalent thermodynamic time constant of a SOFC for overall thermal equation can be of the order of $102 \mathrm{~s}$. Thus, for large timescale (102-103 s), the thermodynamic characteristics will dominate the model dynamic responses [10].

\subsection{Heat exchanger model}

The APU heat management is sensitive to the heat exchanger location and its performance. The reformer outlet flow and inlet air enter the heat exchanger (heat exchanger for the fuel reformer). The most important dynamic term in heat exchanger model is the dynamic response due to the thermal behavior, which is modeled here. The heatexchanger is parallel flow type and balances the SOFC inlet air and fuel temperature. Figure 1 shows a parallel flow heat exchanger.

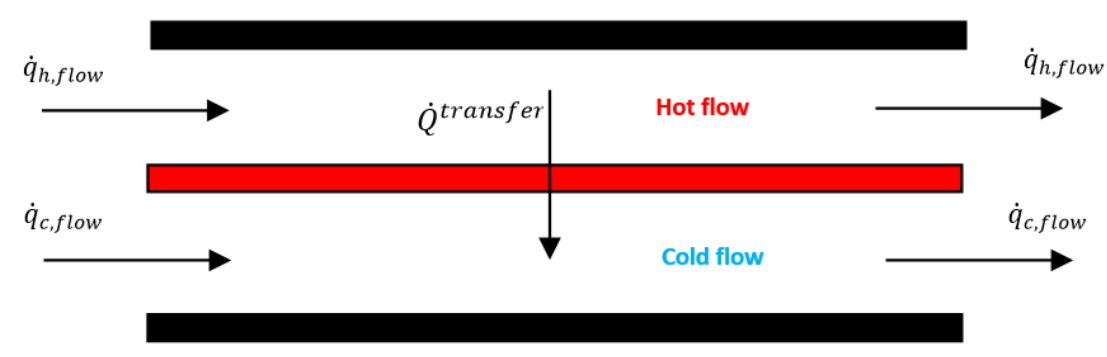

Figure1. A parallel flow heat exchanger 
It is assumed that the hot $(\mathrm{h})$ and cold (c) flow are parallel; the axial heat conduction, kinetic and potential energy is negligible, the specific heat capacity of fluid is constant, the pressure drop is $5 \%$ and the process is adiabatic. There are two significant parameters in heat exchanger modeling: heat transfer rate $(\varepsilon)$ and the maximum heat $\left(\dot{\mathrm{Q}}_{\max }\right)$.

$$
\begin{aligned}
& \varepsilon=\frac{\dot{Q}^{\text {transfer }}}{\dot{\mathrm{Q}}_{\max }} \\
& \rho_{\mathrm{h}} \mathrm{C}_{\mathrm{ph}} \mathrm{V}_{\mathrm{h}} \frac{\mathrm{d}}{\mathrm{dt}} \mathrm{T}_{\mathrm{h}}^{\text {out }}=\dot{\mathrm{m}}_{\mathrm{h}} \mathrm{C}_{\mathrm{ph}}\left(\mathrm{T}_{\mathrm{h}}^{\mathrm{in}}-\mathrm{T}_{\mathrm{h}}^{\text {out }}\right)-\varepsilon \mathrm{C}_{\min }\left(\mathrm{T}_{\mathrm{h}}^{\mathrm{in}}-\mathrm{T}_{\mathrm{c}}^{\mathrm{in}}\right) \\
& \rho_{\mathrm{c}} \mathrm{C}_{\mathrm{pc}} \mathrm{V}_{\mathrm{c}} \frac{\mathrm{d}}{\mathrm{dt}} \mathrm{T}_{\mathrm{c}}^{\text {out }}=\dot{\mathrm{m}}_{\mathrm{c}} \mathrm{C}_{\mathrm{pc}}\left(\mathrm{T}_{\mathrm{c}}^{\mathrm{in}}-\mathrm{T}_{\mathrm{c}}^{\text {out }}\right)+\varepsilon \mathrm{C}_{\min }\left(\mathrm{T}_{\mathrm{h}}^{\mathrm{in}}-\mathrm{T}_{\mathrm{c}}^{\mathrm{in}}\right) \\
& \mathrm{C}_{\min }=\frac{\dot{\mathrm{m}}_{\mathrm{h}} \mathrm{C}_{\mathrm{ph}} \dot{\mathrm{m}}_{\mathrm{c}} \mathrm{C}_{\mathrm{pc}}}{\dot{\mathrm{m}}_{\mathrm{h}} \mathrm{C}_{\mathrm{ph}}+\dot{\mathrm{m}}_{\mathrm{c}} \mathrm{C}_{\mathrm{pc}}}
\end{aligned}
$$

\section{SOFC DYNAMic MOdel VALIDATION}

The dynamic experimental researches for SOFC are very rarely; therefore, most dynamic models aren't validated with experimental data. To evaluate the SOFC dynamic model results in this study, the SOFC voltage time variations with load current step change from 5000 to $3000 \mathrm{~A} \mathrm{~m}-2$ at $1173 \mathrm{~K}$ and fuel utilization factor of $85 \%$, are compared with reference [4] which is shown in Figure 2.

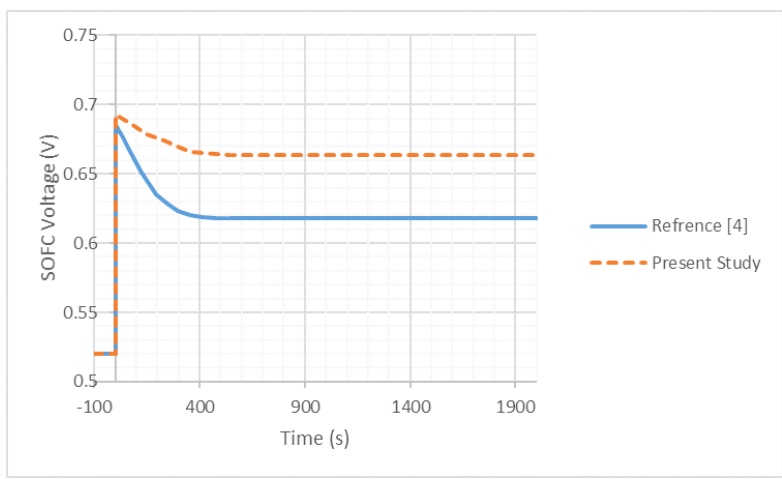

Figure2. Compression of SOFC voltage versus time at load current change in reference [4] and present study

As can be seen, two processes are consistent and initial state of voltage performance is the same in both models. In the present study, the time to reach the steady state is lower and the final voltage is higher. This difference is completely predictable and logical due to the internal reforming of methane in the reference [4]. The geometric and operational characteristics of SOFC stack from reference [4] are shown in the table below.

Table1. The geometric and operational characteristics of SOFC stack from reference [4]

\begin{tabular}{|c|c|c|}
\hline Parameters & Value & unit \\
\hline Anode thickness & $50 \times 10^{-6}$ & $\mathrm{~m}$ \\
\hline Cathode thickness & $50 \times 10^{-6}$ & $\mathrm{~m}$ \\
\hline Electrolyte thickness & $150 \times 10^{-6}$ & $\mathrm{~m}$ \\
\hline Interconnector thickness & $2.5 \times 10^{-3}$ & $\mathrm{~m}$ \\
\hline Specific heat capacity & 2 & $\mathrm{~J} \mathrm{~kg}^{-1} \mathrm{~K}^{-1}$ \\
\hline active area & 105 & $\mathrm{Cm}^{2}$ \\
\hline density & 6600 & $\mathrm{Kg} \mathrm{m}^{-3}$ \\
\hline
\end{tabular}

\section{Results AND Dis CUSSION}

The flight cycle of a Regional jet aircraft is divided into four main stages, which includes ground operations, takeoff and ascent, cruise, and landing and descent. But when the goal is to check the electrical loads of the more electric airplane, the stages change. The flight cycle in this mode consists of four main stages based on different powers: The gate, engine start, climb, and cruise and descent stages.

In the present study, because of only the information on the electric current in the gate, the main engine start, normal cruise, and EO cruise stages are available, only these four stages are considered in the dynamic simulation. Therefore, it is assumed that the request current of take-off stage is equal to the main engine start stage. 
In addition to changing the current load during the flight cycle, the APU input conditions and atmospheric conditions change too. But the atmospheric conditions change much slower than the current load. Therefore, conditions derived from the external environment act like steady state in short period of time. So we will have a quasi-dynamic model that behaves dynamically when the load current changes, but when the environmental conditions change, is a steady state.

In this paper, the suggested NASA regional jet APU was used as a case study [5]. The SOFC is based on the Gen3 Delphi planar SOFC characteristics. The Solid Oxide Fuel Cell stack model has been developed and implemented by the authors in the MATLAB SIMULINK, as described in [1]. The system includes a planar solid oxide fuel cell, an external jet fuel reformer, and a heat exchanger, as shown in Figure 3.

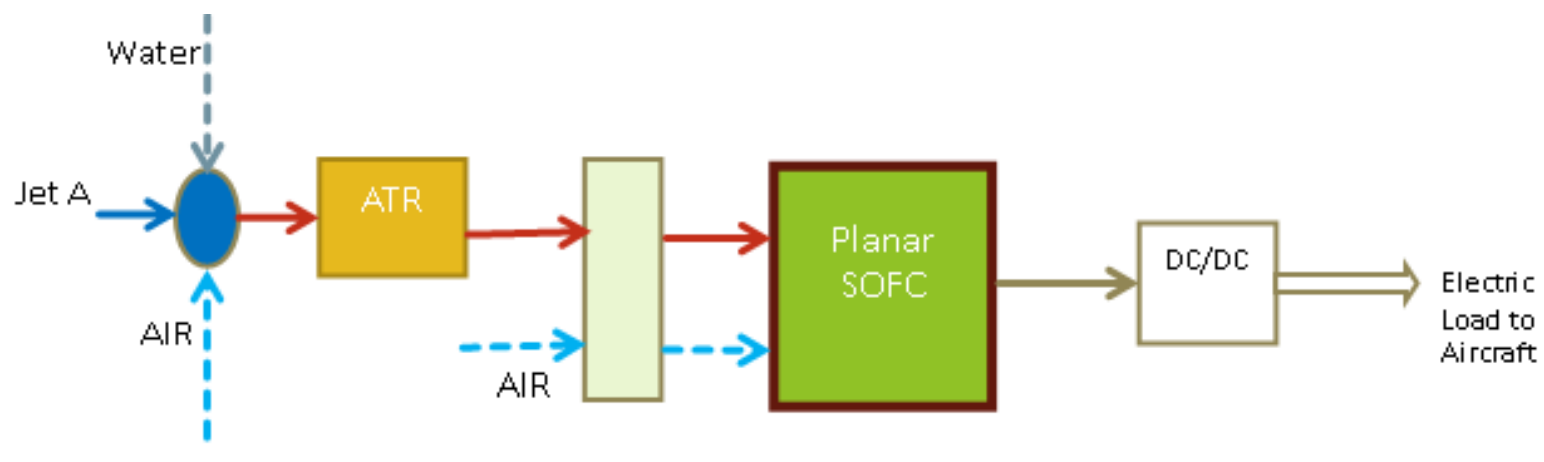

Figure3. Planar ER-SOFC system

The APU system is initially optimized in steady state condition to provide the requested power throughout the flight cycle. The limitation of reducing the performance of the fuel cell by increasing the temperature to more than 1223 Kelvin has been taken into account.

The maximum request power of APU is related to the MES mode and equals to185.3 kw. But the requested power in other flight modes is less than $185.3 \mathrm{kw}$. Therefore, the system is optimized in a steady state that can provide the requested power in the ground and cruise flight modes at the maximum power. Thus, a 128 kilowatts system can produce up to 186 kilowatts of power. Therefore, the maximum power in MES mode will be provided and the weight of the system will be reduced due to the number of SOFC cells reduction. The optimized system parameters of the SOFC / GT APU are used as dynamic model inputs to simulate system performance at different flight stages, as shown in Table 2.

Table2. The parameter's value of ER-SOFC system

\begin{tabular}{|c|c|c|}
\hline Parameters & Value & unit \\
\hline Anode thickness & $510 \times 10^{-6}$ & $\mathrm{~m}$ \\
\hline Cathode thickness & $34 \times 10^{-6}$ & $\mathrm{~m}$ \\
\hline Electrolyte thickness & $10 \times 10^{-6}$ & $\mathrm{~m}$ \\
\hline Interconnector thicknes & $500 \times 10^{-6}$ & $\mathrm{~m}$ \\
\hline effective Nusselt number in the air channel & 5 & - \\
\hline effective Nusselt number in fuel channel & 3.6 & - \\
\hline Interconnectors Emissivity Coefficient & 0.9 & - \\
\hline Anode Specific heat capacity & 466 & $\mathrm{~J} \mathrm{~kg}^{-1} \mathrm{~K}^{-1}$ \\
\hline Cathode Specific heat capacity & 520 & $\mathrm{~J} \mathrm{~kg}^{-1} \mathrm{~K}^{-1}$ \\
\hline Number of cells & - \\
\hline active area & 1350 & $\mathrm{Cm}^{2}$ \\
\hline Fuel utilization & 105 & $\%$ \\
\hline System Power & 85 & $\mathrm{kw}^{-128}$ \\
\hline Inlet fuel cell temperature & 1080 & $\mathrm{~K}$ \\
\hline Fuel flow rate & $6 \times 10^{-3}$ & $\mathrm{Kg} \mathrm{s}^{-1}$ \\
\hline Air flow rate & $4.7 \times 10^{-1}$ & $\mathrm{Kg} \mathrm{s}^{-1}$ \\
\hline HX Pressure drop & 0.5 & $\%$ \\
\hline HX heat transfer coefficient & 1 & - \\
\hline STCR & 1.5 & - \\
\hline OTCR & 0.7 & - \\
\hline
\end{tabular}


In Figure 4, the variations of hot and cold flow temperature of heat exchanger versus time are shown. After about 50 seconds, temperature changes will reach steady state. The results show that when heat transfer coefficient is equal to 1 , the output temperature of both flows will be equal.

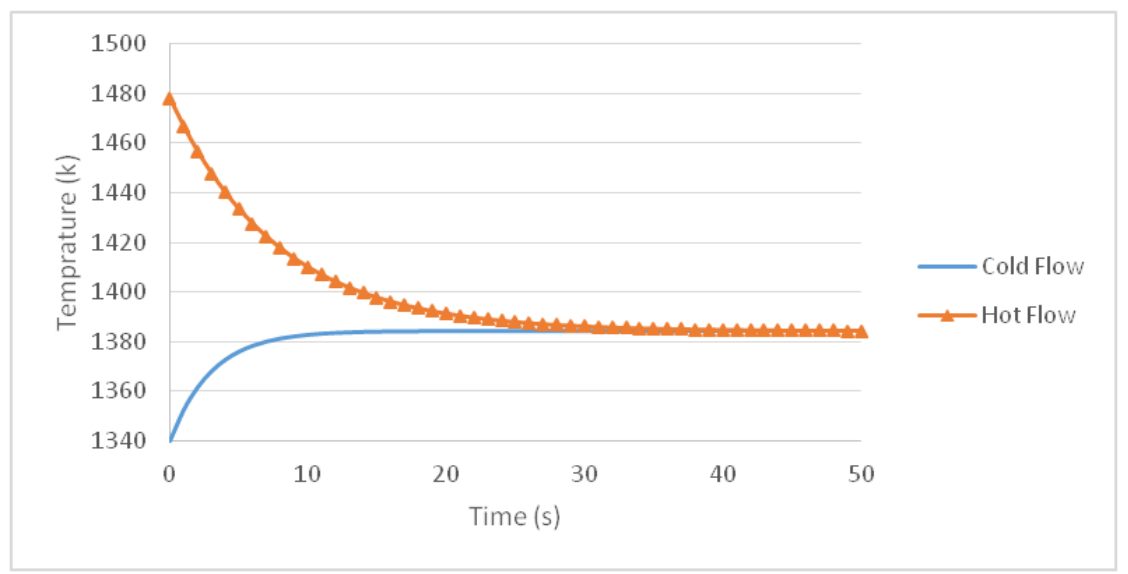

Figure4. The variations of hot and cold flow temperature of heat exchanger versus time

Figure 5 shows that by increasing cold stream flow rate, the outlet temperature of the cold stream decreases. This is because the cold steam is not exposed to the heat exchanger for as long. Therefore the energy transfer rate is lower and less heat is transferred.

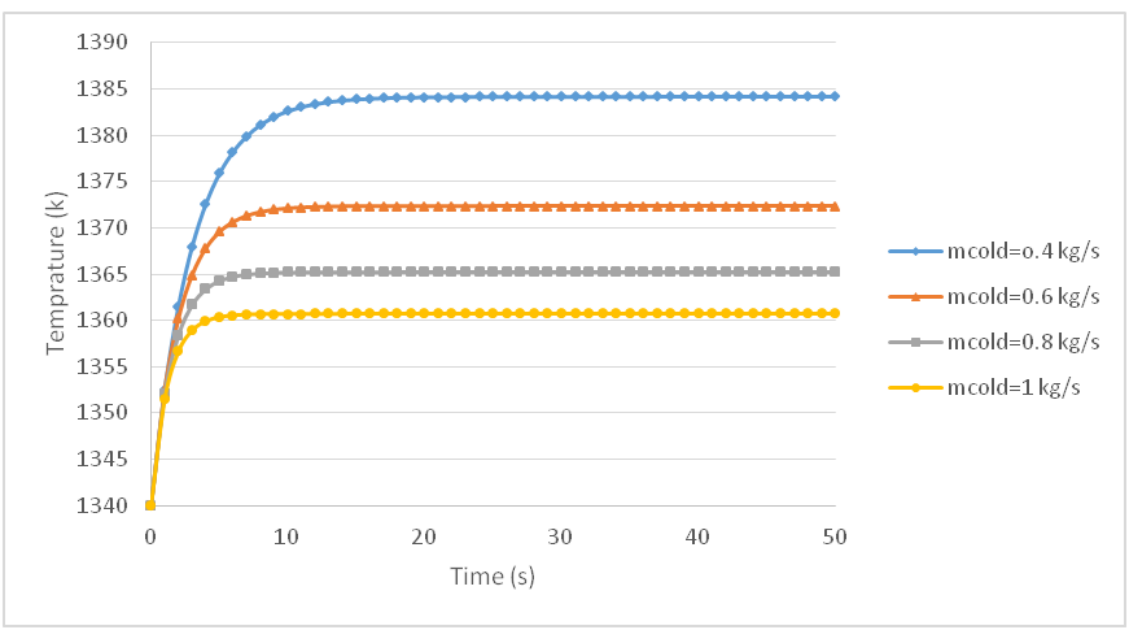

Figure5. The variations of cold stream temperature by increasing inlet mass flow rate

In this section, the transient response of the system is investigated by a sudden change of current load. As a control strategy, the fuel flow rate is assumed constant but the fuel utilization parameter changes versus current load. The dynamic responses of the model are investigated in large timescale in the order of 102$103 \mathrm{~s}$ caused by energy transport $(\tau \mathrm{t})$.

Table3. Represents an estimated Regional Jet mission load profile, based on More-Electric Aircraft (MEA) architecture [5].

\begin{tabular}{|c|c|c|c|c|}
\hline Parameter description & $\begin{array}{c}\text { Gate } \\
(107.5 \mathrm{kw})\end{array}$ & MES (185.3kw) & Cruise (84.3kw) & $\begin{array}{c}\text { Cruise EO } \\
(124.1 \mathrm{kw})\end{array}$ \\
\hline SOFC current demand (A) & 164.3 & 268.6 & 97.8 & 139.3 \\
\hline
\end{tabular}

In addition to the power splits shown in Table 3, the study also considered having the SOFC APU handle the total auxiliary power on the ground and during Cruise.

At time $\mathrm{t}=0$ the load current on the SOFC is increased from 0A to 164A (step1- Gate). The load current is increased from 164A to 268A in step2 (MES) and after that decreased from 268A to 98A (step3Cruise) finally the load current is increased from 98A to 140A (step4- Cruise EO). In this section, firstly, the performance of the SOFC APU in large time scale at four steps is investigated. In this cycle, step changes occur at 100,600, 1800, and 3000 seconds. 


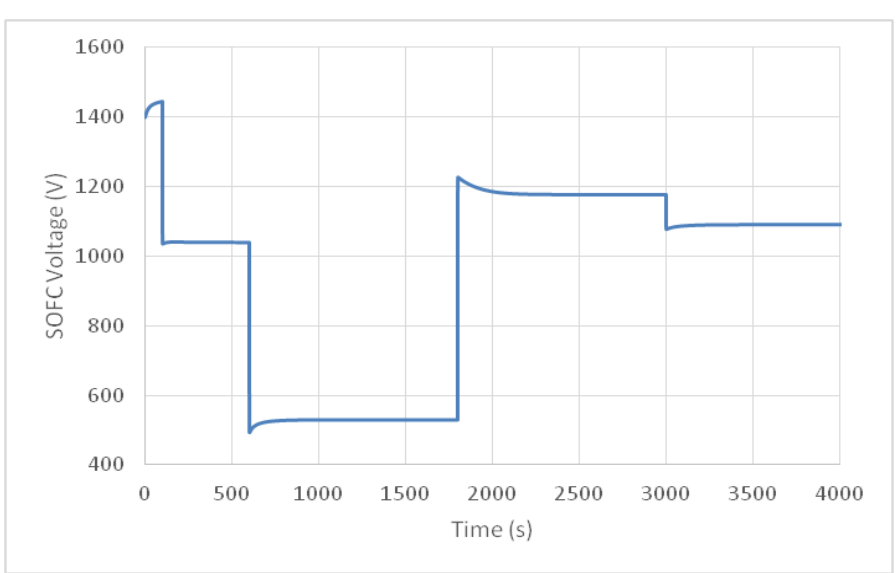

Figure6. The SOFC voltage versus time

In Figure 6, the SOFC voltage versus time is shown by load current step changes of SOFC APU system. As you can see, various components of the system affect the dynamic performance of the fuel cell and the time constant is different in each stage of flight. An undershooting (overshooting) of the cell voltage below (above) the new steady state voltage happens because of the slow thermal response of the SOFC materials.
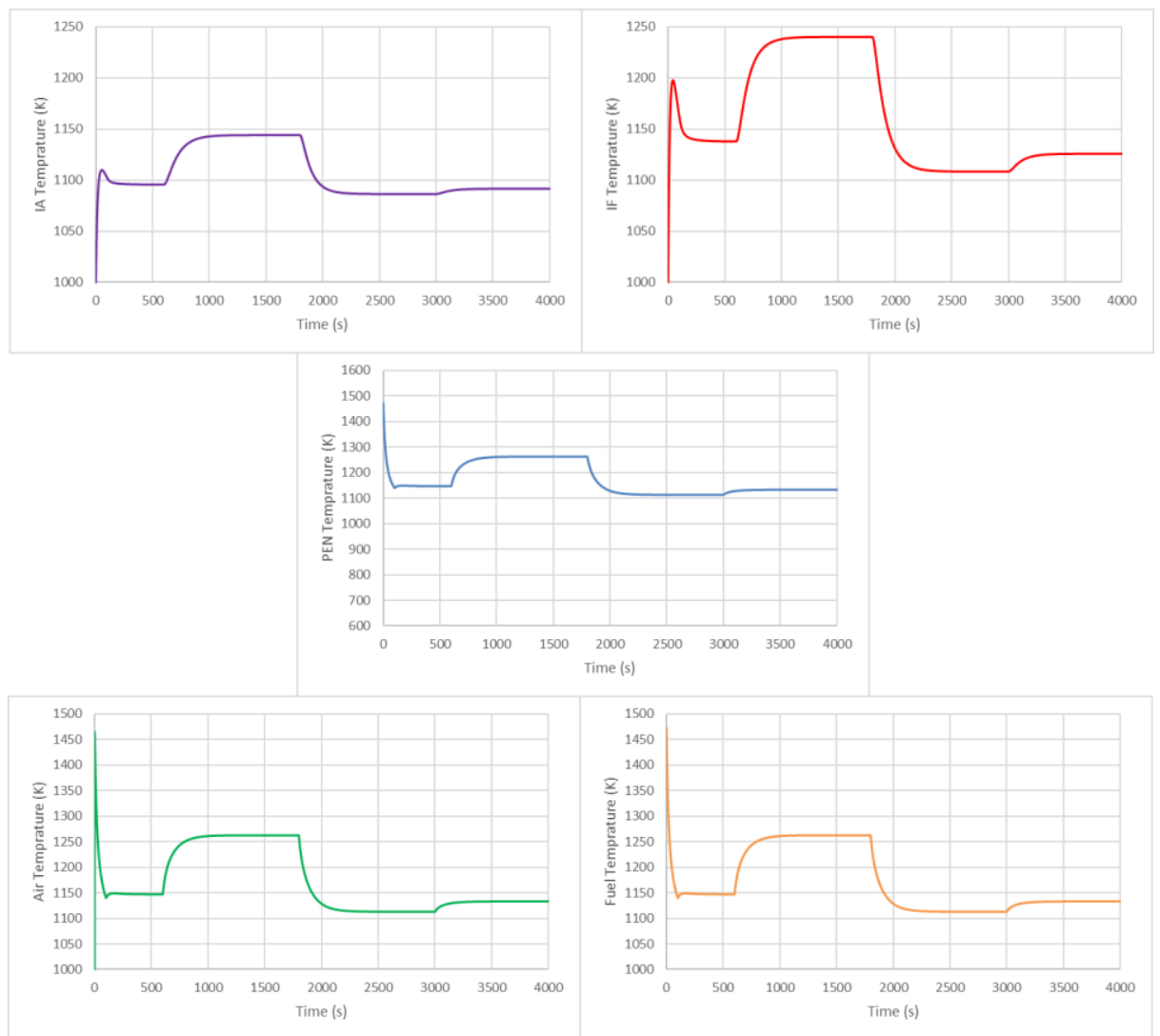

Figure 7. Temperature of five layers versus time

In Figure 7, temperature dynamic response of the system in the regional jet flight cycle is shown. In the first step, because of heat exchanger existence, the temperature suddenly decreases (increases) down (up) the next steady state.

The heat transfer to the interconnectors is done by radiation, which depends on the area, the PEN and interconnectors' temperature, the Emissivity and the Stefan Boltzmann constant. Therefore, the heat transfers to anode interconnector (IF) layer is almost double.

As the air and fuel enter the fuel cell at the same temperature after passing through the heat exchanger, the temperature changes in fuel and air channel are the same except at the beginning of the cycle. 


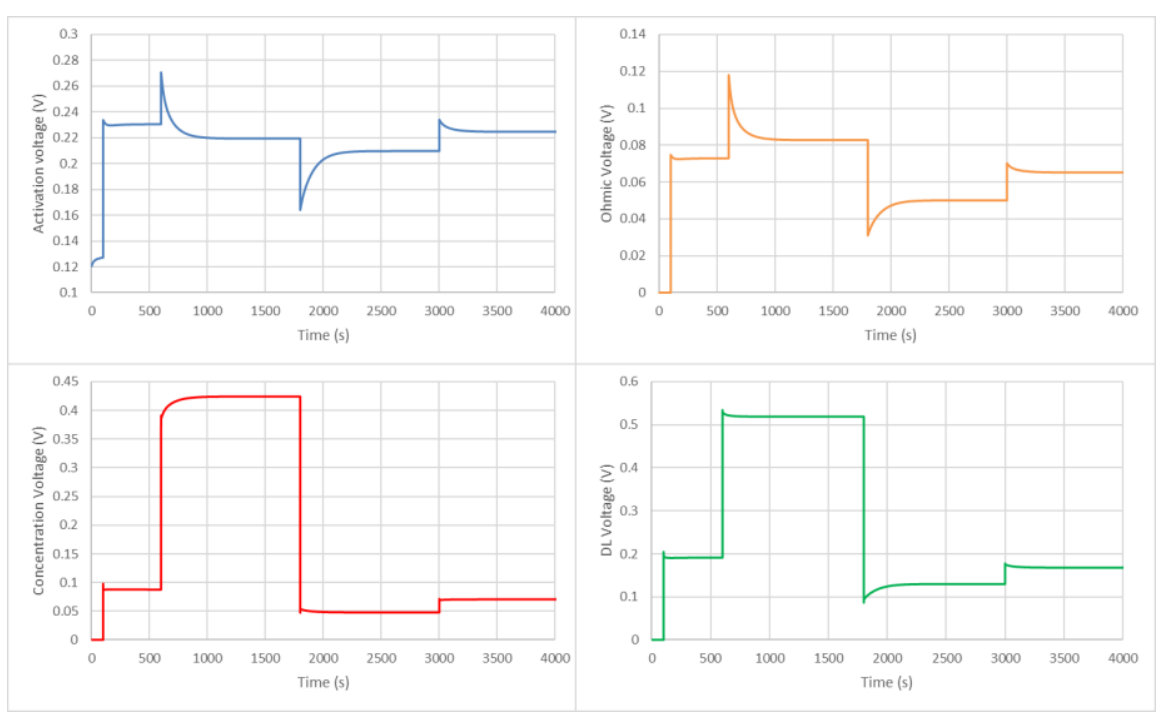

Figure8. The voltage losses of the SOFC versus time

In Figure 8, the voltage losses of the SOFC versus time are shown. As can be seen, by sudden load current changes, the activation and ohmic voltage variations are the highest in the main engine start stage and the lowest in the cruise stage. Conversely, concentration voltage and double layer charging variations are the lowest in the main engine start stage and the highest in the cruise stage.

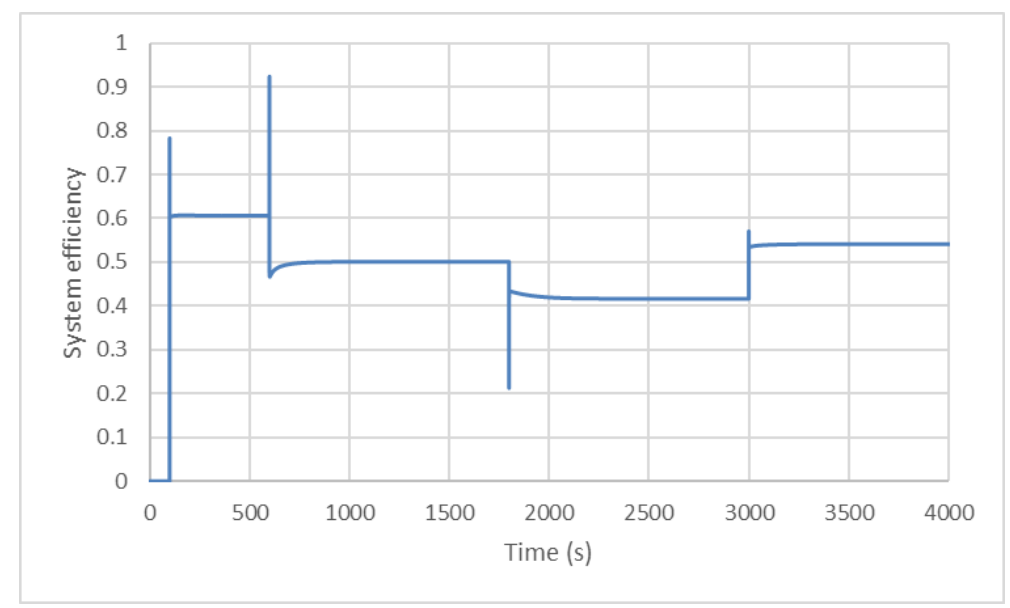

Figure9.The system efficiency versus sudden current load changes

In Figure 9, the system efficiency is shown versus sudden current load changes. Significant transient behavior is observed on each step. The source of these changes is due to the thermal nature of the system. During the SOFC operation, heat is produced. As request current load increases, more temperatures are needed on the system, including a fuelcell. The excess heat needed to supply the request current depends on the operating characteristics of the SOFC. When the current load is reduced, it requires less heat in the system. Thus, the temperature produced by the SOFC is higher than the system needs that do not match the fuel cell performance. Therefore, it takes some time to match the new conditions. The more current load changes, the more impact the system performance will be.

\section{CONCLUS IONS}

In this paper, at first, the system, power range, fuel cell type, fuel type and etc. were specified and then the transient behavior of the fuel cell system to sudden current load changes was evaluated. The focus of this study was on the use of "more electric" aircraft and regional jet as a case study. Modeling results show that current system can't provide the fuel cell temperature by using one heat exchanger, so it is assumed that the air temperature is warmed before entering the heat exchanger to a temperature of 1000 Kelvin. Therefore, it is necessary to correct the system by increasing the number of heat exchangers in the system and using an auxiliary combustion chamber to increase the temperature of the inlet air from the ambient temperature to required temperature. This system will be presented in future articles. 
Results show that the more current load changes, the more impact the system performance will be and by increasing cold stream flow rate, the outlet temperature of the cold stream decreases. By sudden load current changes, the activation and ohmic voltage variations are the highest in the main engine start stage and the lowest in the cruise stage. Conversely, concentration voltage and double layer charging variations are the lowest in the main engine start stage and the highest in the cruise stage. Also, the thermal model shows that the heat transfers to anode interconnector (IF) layer is almost double and temperature changes in fuel and air channel are the same except at the beginning of the cycle.

\section{REFERENCES}

[1] Pourabedin G, Ommi F, Kazempour, P. Modeling and Performance Evaluation of Standalone Solid Oxide Fuel Cell for aircraft APU- I: model-based steady-state performance (Reforming efficacy). International Journal of Engineering \& Technology Sciences, Volume 03, Is sue 06, Pages 393-407, 2015.

[2] Kopasakis G, Brinson T, Credle S, Xu M. A Theoretical Solid Oxide Fuel Cell Modelfor SystemControls and Stability Design, NASA/TM-2006-214104, December 2006.

[3] Lu N, Sun Q Li X, Khaleel M.A, The modeling of a standalone solid-oxide fuel cell auxiliary power unit, Journal of Power Sources, Volume 161, Issue 2, 27 October 2006, Pages 938-948.

[4] Braun R J, Gummalla M, Yamanis, J. systemarchitectures for solid oxide fuel cell-based auxiliary power units in future commercial aircraft applications. Journal of Fuel Cell Science and Technology, AUGUST, 2009; 6: 031015-1.

[5] Mak A, Meier J. Fuel Cell Auxiliary Power Study. Volume 1: RASER Task Order 5, Honeywell Engines, Systems \& Services, Phoenix, Arizona, 2007.

[6] Tornabene R, Wang W Y, Steffen C J, Freeh Joshua E. Development of Parametric Mas s and Volume Models for an Aerospace SOFC/Gas Turbine Hybrid System. Paper No. GT2005-68334, ASME TurboExpo 2005, NASA Glenn Research Center, Cleveland, OH, May 2004.

[7] Freeh, J.E., Pratt, J.W., Brouwer, J., (2004) "Development of a Solid-Oxide Fuel Cell/Gas Turbine Hybrid System Model for Aerospace Applications," GT- 2004-53616, ASME Turbo Expo 2004, Vienna, Austria.

[8] Daggett, D., Eelman, S., and Kristiansson, G., (2003) "Fuel Cell APU for Commercial Aircraft," AIAA-20032660, AIAA International Air and Space Symposium and Exposition: The Next 100 Years, Dayton, OH, USA.

[9] Wang, C., Nehrir, M.H., “A Physically Based Dynamic Model for Solid Oxide Fuel Cells”, IEEE Transactions on Energy Conversion, January 2008.

[10] Bove R, Ubertini S, "Modeling Solid Oxide Fuel Cells-Methods, Procedures and Techniques", Fuel Cells and Hydrogen Energy, Springer, 2008.

\section{AUTHORS' B IOGRAPHY}

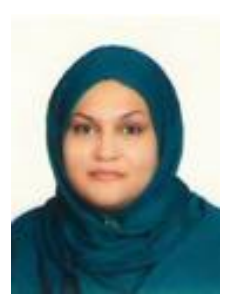

Glnaz Pourabedin, is a $\mathrm{PhD}$ of aerospace engineering from Tarbiat Modares University. She is an Energy Expert in Department of Environment. He is interested to SOFC fuel cell systems, sustainable energy development, climate change and aerospace engineering. Also, she works on dynamic modeling of hybrid SOFC system on aircraft APU.

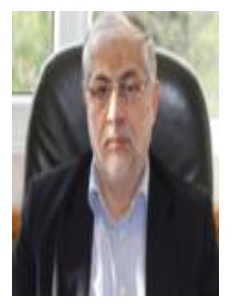

Fathollah Ommi, is an associate professor at Tarbiat Modares University. He has been teaching in his field for more than 30 years. He is expert in aircraft engine and internal combustion engine. Supervised a number of graduate students to obtain a doctorate and master's degree and has a number of research published in the national and international journals.

Citation: Golnaz Pourabedin \&, Fatholah Ommi. (2018)” Dynamic Modeling of Planar Solid Oxide Fuel Cell System for Regional Jet Aircraft Application (Simple System) ', International Journal of Modern Studies in Mechanical Engineering, 4(2), pp.16-28. DOI: http://dx.doi. org/10.20431/2454-9711.0402003

Copyright: (C) 2018 Golnaz Pourabedin, Fatholah Ommi, This is an open-access article distributed under the terms of the Creative Commons Attribution License, which permits unrestricted use, distribution, and reproduction in any medium, provided the original author and source are credited. 